\title{
Is Third Molar Agenesis an Anomaly or Just a Sign of Variation? Prevalence and Manner of Presentation of this Condition in a Sample from the Metropolitan Region of Chile
}

\author{
¿Es la Agenesia del Tercer Molar una Anomalía o Simplemente un Signo de Variación? Prevalencia \\ y Forma de Presentación de esta Condición en una Muestra de la Región Metropolitana de Chile
}

\author{
Moreno, María Trinidad'; Díaz, Alejandro ${ }^{1,2}$; González, Andrea ${ }^{3}$; Manríquez Soto, Germán ${ }^{1,4,5}$ \& Toro-Ibacache, Viviana ${ }^{1,4}$
}

MORENO, M. T.; DÍAZ, A.; GONZÁLEZ, A.; MANRÍQUEZ, S. G. \& TORO-IBACACHE, V. Is third molar agenesis an anomaly or just a sign of variation? Prevalence and manner of presentation of this condition in a sample from the Metropolitan Region of Chile. Int. J. Morphol., 37(4):1382-1386, 2019.

SUMMARY: Agenesis of permanent teeth is the most frequent dental anomaly. The most affected tooth is the third molar (M3), and its congenital absence poses interesting questions from a clinical and evolutionary perspective. M3 agenesis can occur isolated or as part of syndromes. Researchers have reported prevalences that vary largely among populations, between $5 \%$ and $56 \%$, with a mean prevalence of $22.6 \%$. Previous Chilean studies, mainly in Northern populations, have determined a prevalence between $19.8 \%$ and 26.7 $\%$. The aim of this work was to assess the prevalence of M3 agenesis and to characterize its presentation in a sample from Santiago, the largest to date in a M3 agenesis prevalence study in Chile. In this study, 535 panoramic radiographies and clinical histories of patients from the Dental Clinic of the Universidad de Chile were used to determine prevalence and distribution according to sex, affected tooth, and location (left or right; maxilla or mandible). The Chi-square test was used to assess statistical significance in distribution. The calculated M3 agenesis prevalence was of $12.89 \%$. No statistically significant differences were found between sexes, sides or location within the jaws. The agenesis of one third molar was more common, then two, three and finally of all the third molars. The prevalence of M3 agenesis in the sample is $12.89 \%$, with a random manner of presentation. We propose that as it currently stands, M3 agenesis should be considered an anatomical variation rather than a developmental anomaly.

KEY WORDS: Third molar; Agenesis; Hypodontia.

\section{INTRODUCTION}

Dental anomalies are relatively common in different populations. They are alterations of the embryological development of the dentition that result in an altered number of teeth, size, form, position, color or in a dysplasia of the dental tissues. Agenesis is the absence of a dental organ during the embryonic development. The agenesis of permanent teeth is the most common dental anomaly (Bailit, 1975), and the most affected tooth is the third molar (Larmour et al., 2005).

This can be present as an isolated condition or as part of a syndrome (Vastardis, 2000). It is observed in both dentitions, although it is more common in the permanent dentition. The third molar is the tooth that most appears with agenesis, followed by the second lower premolar (3-4 \%), upper lateral incisor (1-2.5\%) and second upper premolar (1-2\%) (Brook et al., 2014).

Individuals with dental agenesis can be affected in different ways. Aesthetic and functional problems are particularly evident when anterior teeth are compromised, affecting selfesteem, communication capacity and quality of life. In case of the agenesis of the third molar, positive or negative consequences seem less obvious, and clinicians may never

\footnotetext{
${ }^{1}$ Centro de Análisis Cuantitativo en Antropología Dental, Facultad de Odontología, Universidad de Chile.

${ }^{2}$ Departamento del Niño y Ortopedia Dentomaxilar, Facultad de Odontología, Universidad de Chile.

${ }^{3}$ Odontóloga, práctica privada.

${ }^{4}$ Instituto de Investigación en Ciencias Odontológicas, Facultad de Odontología, Universidad de Chile.

${ }^{5}$ Departamento de Antropología, Facultad de Ciencias Sociales, Universidad de Chile.

Financiamiento: Proyecto FIOUCh 10/2017 (Facultad de Odontología, Universidad de Chile).
} 
MORENO, M. T.; DÍAZ, A.; GONZÁLEZ, A.; MANRÍQUEZ, S. G. \& TORO-IBACACHE, V. Is third molar agenesis an anomaly or just a sign of variation? Prevalence and manner of presentation of this condition in a sample from the Metropolitan Region of Chile. Int. J. Morphol., 37(4):1382-1386, 2019.

have to deal with them. However, the question about the origin of this condition remains, not only in dentistry but also in evolutionary biology and biological anthropology. Also certain morphological changes have been associated with its congenital absence such as a decrease in size of the maxillary and mandibular bones (Kajii et al., 2004), a decrease in jaw length, lower facial height, decreased mandibular plane angle and decreased gonial angle (Sugiki et al., 2018). Fernández et al. reported an association between third molar agenesis and cleft lip and palate (Fernandez et al., 2018). In contrast with the agenesis of the rest of the teeth, no aesthetic alterations or functional difficulties are reported. In fact, the congenital absence of the M3 may even be seen as an advantage, since there would be no risk of situations like molar impaction and pericoronitis.

The reported prevalence of M3 agenesis varies among populations. Values such as $5.32 \%$ in the Ugandan population and $56 \%$ in a sample from Southern India have been observed (Carter \& Worthington, 2015). A metanalysis by Carter $\&$ Worthington calculated an average world prevalence of $22.6 \%$ from the existing literature.

In North America (USA, Canada and Mexico) the average prevalence of M3 agenesis is $17.88 \%$, whereas in South America is $18.19 \%$. For the latter metanalysis in South America nine investigations were included from Brazil, four from Chile and two from Colombia (Carter \& Worthington). Different studies in Latin American countries have calculated a prevalence of M3 agenesis of $21 \%$ in Colombia (Espinal Botero et al., 2009), $26 \%$ in Mexico (Ramiro-Verdugo et al., 2015) and $29.3 \%$ in Cuba (González Espangler et al., 2014). However, different values were reported in studies in the same country. Lower values of agenesis were described for another sample from Colombia (10.6\%) and Cuba (12.45\%). Differences in the observed prevalence within a country suggest the presence of variations among related populations, and a possible random pattern in the occurrence of M3 agenesis.

In Chile, the first M3 agenesis study was performed in 1995, using a sample of 116 individuals from the Metropolitan Region, where a prevalence of $19.8 \%$ was calculated based on unitary retroalveolar xrays of the mandible (Martínez et al., 1995). To the best of our knowledge, no further studies were made until the next decade, when a prevalence of $24.75 \%$ was determined for the Chilean populations in Antofagasta (García-Hernández et al., 2008), $26.7 \%$ in the Atacameño ethnic group (García-Hernández \& Beltrán Varas, 2008) and $21.79 \%$ in the Aymara population (García-Hernández \& Beltrán Varas, 2009).
We seek to generate up-to-date knowledge in this topic that aids to describe and understand the causes and manner of presentation of M3 agenesis and the possible anatomical and clinical consequences of it. Specifically, the aim of this study is to determine the prevalence of the agenesis of a sample of the Metropolitan Region in Chile and its characteristics of presentation according to sex, location and symmetry. We chose individuals from this area as a potentially representative sample of the country, since it concentrates $38 \%$ of the total population and its ancestry corresponds to 39.12\% Amerindian (Aymara and Mapuche), $56.45 \%$ European and $4.53 \%$ African (ancestria.chilegenomico.cl), which is very close to the average data for the country, which was estimated to be $44.34 \%$ Amerindian (without separating Aymara \& Mapuche), $51.85 \%$ European, and 3.81 \% African in 2014 (Fuentes et al., 2014), corroborated by more recent studies using enriched ancestry informative markers (AIMs) (www.chilegenomico.cl/datos-genomicos). To study how M3 agenesis presents in the sample, we tested the null hypothesis that the characteristics of M3 agenesis are independent of sex and location (maxilla and mandible, right and left sides).

\section{MATERIAL AND METHOD}

Panoramic radiographs from 535 patients of the Dental Clinic of the University of Chile were used. Recruited individuals were older than 14 years and had no history of severe maxillofacial trauma, congenital malformation nor orthognathic surgery and no previous history of third molar extractions.

The radiographs of the individuals were worked anonymously and only relevant information of each participant was known (sex, age, presence of agenesis, identification of the absent teeth). Descriptive statistics of the prevalence of agenesis per sex, affected tooth, and location (left or right; maxilla or mandible) were calculated. The Chi-square test was used for the test of the null hypothesis using PAST (Paleontological Statistics, Version 3.20). Significant $\mathrm{p} \leq 0.05$ was considered to reject the null hypothesis.

The post-hoc statistical power of the analyses was > 0.8, calculated using G*Power (Faul et al., 2009). The process for obtaining patient data as well as the analytical approach of this study was authorized by the Scientific Ethics Committee of the Universidad de Chile School of Dentistry (No. 2016/29). 
MORENO, M. T.; DÍAZ, A.; GONZÁLEZ, A.; MANRÍQUEZ, S. G. \& TORO-IBACACHE, V. Is third molar agenesis an anomaly or just a sign of variation? Prevalence and manner of presentation of this condition in a sample from the Metropolitan Region of Chile. Int. J. Morphol., 37(4):1382-1386, 2019.

\section{RESULTS}

Table I summarizes the prevalence of agenesis per sex. There was no statistically significant difference in the distribution between females and males $\left(\chi^{2}=2.371, \mathrm{p}=\right.$ $0.123)$.

Table II summarizes the distribution of agenesis according to sex and the affected tooth. Within females there was no statistically significant difference between affected teeth $\left(\chi^{2}=0.703, p=0.521\right)$; the same happened for males $\left(\chi^{2}=0.173, \mathrm{p}=0.758\right)$.

Table III summarizes the frequency of agenesis according to location. With the sample pooled for both sexes, there were no statistically significant differences between bones (maxilla or mandible) and sides (right or left) $\left(\chi^{2}=\right.$ $0.874, \mathrm{p}=0.349)$.

Finally, all the individuals were organized according the total number of M3s with agenesis. Table IV summarizes the frequency of the number of affected M3.

Table I. Prevalence of M3 agenesis per sex.

\begin{tabular}{lccc}
\hline Sex & $\mathrm{N}^{\circ}$ individuals & $\mathrm{N}^{\circ}$ individuals with & Percentage \\
\hline Male & 224 & 23 & $10.26 \%$ \\
Female & 311 & 46 & $14.79 \%$ \\
Total & 535 & 69 & $12.89 \%$ \\
\hline
\end{tabular}

Table II. Distribution of agenesis according to sex and affected tooth.

\begin{tabular}{lcccccc}
\hline Tooth (ID) & Male & Percentage & Female & Percentage & Total & Percentage \\
\hline Right maxillarv (18) & 13 & $31.71 \%$ & 26 & $29.55 \%$ & 39 & $30.23 \%$ \\
Left maxillarv (28) & 9 & $21.95 \%$ & 19 & $21.59 \%$ & 28 & $21.70 \%$ \\
Left mandibular (38) & 9 & $21.95 \%$ & 22 & $25 \%$ & 31 & $24.04 \%$ \\
Right mandibular (48) & 10 & $24.39 \%$ & 21 & $28.36 \%$ & 31 & $24.04 \%$ \\
\hline
\end{tabular}

Table III. Number of affected M3s according to the bone (maxilla or mandible) or side (right or left)

\begin{tabular}{lcc}
\hline & Right & Left \\
\hline Maxilla & 39 & 28 \\
Mandible & 31 & 31 \\
\hline
\end{tabular}

\section{DISCUSSION}

Our observed prevalence is lower than the one reported worldwide, however, similar to values found in other studies conducted in America. It has been reported in Brazil a prevalence of $10.83 \%$ (Oliveira \& Serra Negra, 1985), $10.6 \%$ in Colombia (Bastidas \& Rodríguez, 2004) and $16.36 \%$ in Venezuela (Méndez \& Contreras, 2006). When comparing prevalence among continents, it is observed that the values of South America (18.19\%) are lower than those reported in Europe (21.6 \%) and Asia (29.71\%), while Africa represents the continent with the lowest prevalence $(5.74 \%)$. Our study reports a lower value than the average in South America. Although there may be many reasons behind our found prevalence and the variations among countries, we suggest that ancestry may play a role. The genetics of agenesis has not been fully dilucidated but several genes may be involved (Vastardis et al., 1996; Kulkarni et al., 2011; Yu et al., 2016; Juuri \& Balic, 2017). Since ancestry varies among continents and countries, some populations
Table IV. Number and percentage of the patients according to the number of affected teeth

\begin{tabular}{lcc}
\hline No. of affected M3s & $\begin{array}{c}\text { No. of individuals } \\
\text { (total agenesis=69) }\end{array}$ & Percentage \\
\hline One & 33 & $47.8 \%$ \\
Two & 19 & $27.5 \%$ \\
Three & 10 & $14.5 \%$ \\
Four & 7 & $10.2 \%$ \\
\hline
\end{tabular}

with a more homogeneous genetic background may have either the highest or lowest prevalence, while more hybrid populations would present average or close-to-average values, between the extremes. The origin of our sample covers several areas of the Metropolitan Region of Chile, which concentrates a $38 \%$ of the Chilean population, and thus the individuals may be representative of a large proportion of the urban Chilean population. The ancestry of Chileans corresponds to $44 \%$ Amerindian and $56 \%$ no Amerindian (European/African) (www.chilegenomico.cl/ datos-genomicos). Thus, our prevalence value falls between the largest and lowest. On the contrary, Martínez et al. found in Amerindian populations of Northern Chile prevalence closer to the highest reported values. Now, within the populations with "in-between" M3 agenesis values, our observed prevalence is comparatively low, and not only ancestry but also sampling could be factor to look for an explanation. Some of the radiographs included are of patients 
from the maxillofacial surgery clinic, where several patients consulted for the need of M3 extractions. However, this origin corresponds only to $6.2 \%$ of the total sample and their exclusion did not alter the results. The vast majority of the radiographs came from patients from the orthodontic clinic. Thus we discard the effect of sampling in our observed prevalence. Further studies are required to test the hypothesis of third molar agenesis linked to the homogeneity of ancestries. The relation of M3 agenesis to sex, affected tooth and location was not statistically significant. In the case of bones, there was a tendency of higher proportion of agenesis in the maxilla. In the case of the side, agenesis was more common in the right side. The most affected M3 was 18, which is located in the upper right maxilla. Agenesis was also more common in women. Kaji et al. (2004) discuss that this may be due to the fact that women have smaller jaws than men and therefore, they would constraint M3 development. Our lack of statistical significance in distribution between sexes and locations despite the large sample size, and that it is more common to have one M3 affected, then two, and three, shows that the distribution of agenesis is random. The question arises then, should M3 agenesis in modern populations be considered as a developmental anomaly? It seems to be the feature of common presentation rather than a developmental problem. Furthermore, it is not linked to aesthetic or functional consequences (but is, to the ancestral trait of an existing third molar). The literature discusses M3 agenesis as part of the evolutionary process of humans, but there are no conclusive studies regarding this hypothesis. When analyzing the historical prevalence data, it is observed that the prevalence values have remained constant during the last years, as described by Carter \& Worthington, who recorded studies from 1930 to 2015. It would be interesting to have access to large retrospective data to assess the presence of agenesis starting with ancient populations of Chile, genetically non-hybrid, to evaluate if there truly is an important evolutionary change for the teeth and its repercussion in the shape of the maxilla and mandible. Also, if there were samples from other regions of the continent, a comparison could be made between Latin American populations.

In conclusion, the prevalence of agenesis of the third molar in a sample of the Metropolitan Region corresponding to patients of the University of Chile Dental Clinic is 12.89 $\%$, which is lower to the reported mean world prevalence. In terms of the manner of presentation of the condition, the null hypothesis was confirmed, since M3 agenesis presentation was independent of sex and location (maxilla and mandible, right and left sides). Finally, in the study in our sample it was more common to present agenesis of one third molar, then of two, three and finally of all third molars.
MORENO, M. T.; DÍAZ,A.; GONZÁLEZ,A.; MANRÍQUEZ, S. G. \& TORO-IBACACHE, V. ¿Es la agenesia del tercer molar una anomalía o simplemente un signo de variación?. Prevalencia y forma de presentación de esta condición en una muestra de la Región Metropolitana de Chile. Int. J. Morphol., 37(4):1382-1386, 2019.

RESUMEN: La agenesia de dientes definitivos es la anomalía dental más común. El diente más afectado es el tercer molar (M3), y su ausencia congénita plantea preguntas interesantes desde una perspectiva clínica y evolutiva. La agenesia de M3 puede ocurrir de manera aislada o asociada a síndromes. Estudios a nivel mundial reportan una prevalencia variable entre poblaciones: $5 \%$ a $56 \%$, con una prevalencia media del $22,6 \%$. Estudios chilenos anteriores, principalmente en poblaciones del norte, han determinado una prevalencia entre $19,8 \%$ y $26,7 \%$. El objetivo de este trabajo fue determinar la prevalencia de agenesia de M3 y caracterizar su presentación en una muestra de Santiago, la más grande hasta la fecha en un estudio de prevalencia de agenesia de M3 en Chile. Se utilizaron 535 radiografías panorámicas y antecedentes de pacientes atendidos en la Clínica Odontológica de la Universidad de Chile para evaluar la prevalencia y modo de presentación de la agenesia de M3. Se analizó su distribución según ubicación, sexo y simetría, mediante test estadístico Chi-cuadrado. Se calculó una prevalencia de agenesia de M3 de 12,89\%, sin un patrón claro ni estadísticamente significativo en su distribución. Fue más común la agenesia de un tercer molar, luego de dos, tres y finalmente de todos los terceros molares. La prevalencia de agenesia en una muestra de la Región Metropolitana es de $12,89 \%$ y su distribución es aleatoria según la ubicación, sexo y simetría. Se propone que esta condición actualmente debiera considerarse como una variación anatómica más que a una anomalía del desarrollo.

PALABRAS CLAVE: Tercer molar; Agenesia; Hipodoncia.

\section{REFERENCES}

Bailit, H. L. Dental variation among populations. An anthropologic view. Dent. Clin. North Am., 19(1):125-39, 1975.

Bastidas, M. A. \& Rodríguez, A. M. Agenesia dental en pacientes jóvenes. Rev. Estomatol., 12(2):34-43, 2004.

Brook, A. H.; Jernvall, J.; Smith, R. N.; Hughes, T. E. \& Townsend, G. C. The dentition: the outcomes of morphogenesis leading to variations of tooth number, size and shape. Aust. Dent. J., 59 Suppl. 1:131-42, 2014.

Carter, K. \& Worthington, S. Morphologic and Demographic Predictors of Third Molar Agenesis: A Systematic Review and Meta-analysis. J. Dent. Res., 94(7):886-94, 2015.

Espinal Botero, G.; Manco Guzmán, H. A.; Aguilar Méndez, G.; Castrillón Pino, L.; Rendón Giraldo, J. E. \& Marín Botero, M. L. Estudio retrospectivo de anomalías dentales y alteraciones óseas de maxilares en niños 5 a 14 años de las clínicas de la Facultad de Odontología de la Universidad de Antioquia. Rev. Fac. Odontol. Univ. Antioq., 21(1):5064, 2009.

Faul, F.; Erdfelder, E.; Buchner, A. \& Lang, A. G. Statistical power analyses using $\mathrm{G}^{*}$ Power 3.1: tests for correlation and regression analyses. Behav. Res. Methods, 41(4):1149-60, 2009. 
MORENO, M. T.; DÍAZ, A.; GONZÁLEZ, A.; MANRÍQUEZ, S. G. \& TORO-IBACACHE, V. Is third molar agenesis an anomaly or just a sign of variation? Prevalence and manner of presentation of this condition in a sample from the Metropolitan Region of Chile. Int. J. Morphol., 37(4):1382-1386, 2019.

Fernandez, C. C. A.; Pereira, C. V. C. A.; Luiz, R. R.; Faraco, I. M. Jr.; Marazita, M. L.; Arnaudo, M.; de Carvalho, F. M.; Poletta, F. E.; Mereb, J. C.; Castilla, E. E.; et al. Third molar agenesis as a potential marker for craniofacial deformities. Arch. Oral Biol., 88:19-23, 2018.

Fuentes, M.; Pulgar, I.; Gallo, C.; Bortolini, M. C.; Canizales-Quinteros, S.; Bedoya, G.; González-José, R.; Ruiz-Linares, A. \& Rothhammer, F. Geografía génica de Chile. Distribución regional de los aportes genéticos americanos, europeos y africanos. Rev. Med. Chile, 142(3):281-9, 2014.

García-Hernández, F. \& Beltrán Varas, V. J. Third molar agenesis in native ethnia from North of Chile: Atacamenos or Lican Antai. Int. J. Morphol., 26(3):583-90, 2008.

García-Hernández, F. \& Beltrán Varas, V. J. Third molar agenesis in native ethnia from North of Chile: Aymaras. Int. J. Morphol., 27(1):151-8, 2009.

García-Hernández, F.; Toro Yagui, O.; Vega Vidal, M. \& Verdejo Meneses, M. Third molar agenesis in young people between 14 and 20 years of Age, Antofagasta, Chile. Int. J. Morphol., 26(4):825-32, 2008.

González Espangler, L.; Mok Barceló, P.; de la Tejera Chillón, A.; George Valles, Y. \& Leyva Lara, M. L. Caracterización de la formación y el desarrollo de los terceros molares. Medisan, 18(1):34-44, 2014.

Juuri, E. \& Balic, A. The Biology Underlying Abnormalities of Tooth Number in Humans. J. Dent. Res., 96(11):1248-56, 2017.

Kajii, T. S.; Sato, Y.; Kajii, S.; Sugawara, Y. \& Iida, J. Agenesis of third molar germs depends on sagittal maxillary jaw dimensions in orthodontic patients in Japan. Angle Orthod., 74(3):337-42, 2004.

Kulkarni, M.; Agrawal, T. \& Kheur, S. Tooth agenesis: newer concept. $J$. Clin. Pediatr. Dent., 36(1):65-9, 2011.

Larmour, C. J.; Mossey, P. A.; Thind, B. S.; Forgie, A. H. \& Stirrups, D. R. Hypodontia--a retrospective review of prevalence and etiology. Part I. Quintessence Int., 36(4):263-70, 2005.

Martínez, M. S.; Concha, S. G. \& San Pedro, V. J. Estudio radiográfico de terceros molares inferiores en una muestra de individuos de 18 a 20 años. Rev. Fac. Odontol. Univ. Chile, 13(1):43-9, 1995.

Méndez, A. D. C. \& Contreras, R. C. C. Anomalías de número en pacientes con dentición mixta. Rev. Latinoam. Ortod. Odontopediatr., 2006. Available from: https://www.ortodoncia.ws/publicaciones/2006/art-3/

Oliveira, O. L., \& Serra Negra, E. Agenesia de terceiros molares em negros brasileiros. Arq. Centro Estud. Curso Odontol., 21/22(2/1):103$11,1985$.

Ramiro-Verdugo, J.; De Vicente-Corominas, E.; Montiel-Company, J. M.; Gandía-Franco, J. L. \& Bellot-Arcís, C. Association between third molar agenesis and craniofacial structure development. Am. J. Orthod. Dentofacial Orthop., 148(5):799-804, 2015.

Sugiki, Y.; Kobayashi, Y.; Uozu, M. \& Endo, T. Association between skeletal morphology and agenesis of all four third molars in Japanese orthodontic patients. Odontology, 106(3):282-8, 2018.

Vastardis, H. The genetics of human tooth agenesis: new discoveries for understanding dental anomalies. Am. J. Orthod. Dentofacial Orthop., 117(6):650-6, 2000.

Vastardis, H.; Karimbux, N.; Guthua, S. W.; Seidman, J. G. \& Seidman, C. E. A human MSX1 homeodomain missense mutation causes selective tooth agenesis. Nat. Genet., 13(4):417-21, 1996.

Yu, P.; Yang, W.; Han, D.; Wang, X.; Guo, S.; Li, J.; Li, F.; Zhang, X.; Wong, S. W.; Bai, B.; et al. Mutations in WNT10B are identified in individuals with oligodontia. Am. J. Hum. Genet., 99(1):195-201, 2016.
Corresponding author:

Germán Manríquez Soto

Viviana Toro-Ibacache

Centro de Análisis Cuantitativo en Antropología Dental

Facultad de Odontología

Universidad de Chile

Olivos 943

Independencia

Región Metropolitana

CHILE

\section{Email: gmanriquezs@odontologia.uchile.cl mtoroibacache@odontologia.uchile.cl}

Received: 09-05-2019

Accepted: 23-05-2019 